\title{
Ekonomik Büyüme Oranını Etkileyen Faktörlerin Kantil Regresyon ile İncelenmesi: Türkiye Örneği
}

\section{Investigation of Factors Affecting Economic Growth Rate with Quantile Regression: The Instance of Turkey}

Yüksel Akay Ünvan ${ }^{a^{*}}$, Oğuzhan Demirel ${ }^{\text {b }}$

${ }^{a}$ Doç. Dr., Ankara Yıldırım Beyazıt Üniversitesi, İşletme Fakültesi, Bankacılık ve Finans Bölümü, 06010, Ankara/Türkiye ORCID: 0000-0002-0983-1455

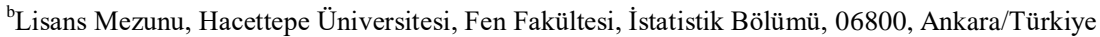

ORCID: 0000-0003-4352-6531

\begin{tabular}{l} 
MAKALE BİLGISİ \\
\hline Makale Geçmişi: \\
Başvuru tarihi: 31 Mart 2020 \\
Düzeltme tarihi: 15 Ekim 2020 \\
Kabul tarihi: 21 Ekim 2020 \\
\hline Anahtar Kelimeler: \\
Ekonomik Büyüme \\
Ekonomik Büyüme Oranı \\
En Küçük Kareler \\
Kantil Regresyon
\end{tabular}

\section{AR T ICLE INFO}

\section{Article history:}

Received 31 March 2020

Received in revised form 15 October 2020

Accepted 21 October 2020

\section{Keywords:}

Economic Growth

Economic Growth Rate

Least Squares

Quantile Regression
ÖZ

Bu çalışma, Türkiye'de son yıllarda dalgalı bir hareket sergileyen ekonomik büyüme oranını etkileyen faktörleri incelemek amacıyla yapılmıştır. Ekonomik büyüme oranı, dış borç stoku, tüketici fiyatları endeksi (TÜFE) bazlı reel efektif döviz kuru, reel faiz oranı ve tüketici fiyatları endeksine ait 2010-Q1 ve 2019-Q3 dönemi verileri kullanılarak bir veri seti oluşturulmuştur. Öncelikle değișkenlerin durağanlıkları, Augmented Dickey-Fuller (ADF) testiyle sınanmıștır. Değişkenlerin 1.dereceden farkları alınarak durağanlaştırma sağlanmıştır. Daha sonra, en küçük kareler (EKK) yöntemi kullanılarak bir regresyon modeli kurulmuştur. Fakat bu regresyon modeli, aykırı gözlemler içerdiğinden dolayı kantil regresyon yöntemi kullanılmıştır. Sonuçlara göre, Türkiye'ye ait ekonomik büyüme oranını; TÜFE bazlı reel efektif döviz kuru ve yıllık tüketici fiyatları endeksi negatif etkilemektedir.

\section{AB S T R A C T}

The aim of this study has examined the factors affecting the economic growth rate in Turkey, which has experienced a wavy pace in recent years. A data set has created using data of the 2010Q1 and 2019-Q3 periods of economic growth rate, external debt stock, consumer price index (CPI), CPI-based real effective exchange rate (REER), and real interest rate. Firstly, stabilization has been achieved by taking the 1st-degree differences of variables with the ADF test. Then, a regression model has established using the Ordinary Least Squares (OLS) method. However, due to this regression model contained outlier observations, the quantile regression method has been utilized. According to the results, CPI and CPI-based REER negatively affect the economic growth rate of Turkey.

\section{Giriș}

Günümüzde ülkeler; gelişmemiş, gelişmekte olan ve gelişmiş olmak üzere 3 ayrı grupta değerlendirilmektedir. $\mathrm{Bu}$ değerlendirme yapılırken en belirleyici etken şüphesiz ülkelerin sahip olduğu ekonomik durumlardır. Ülke ekonomilerinin durumları belirlenirken birçok yön değerlendirilmektedir. Bu değerlendirmeler çeşitli faktörler göz önünde bulundurularak yapılmaktadır. Bir ülke ekonomisinin durumunu anlamada en önemli göstergelerden birisi olan ekonomik büyüme, şüphesiz bu faktörlerden birisidir. Ekonomik büyüme oranı en genel ifadeyle Gayri Safi Yurtiçi Hasıla (GSYH)'nın artış oranı olarak tanımlanabilir. Fakat ekonomi bir ülkenin bütün unsurlarını içerdiğinden ekonomik büyüme çeşitli politik ve ekonomik hareketlerden etkilenebilmektedir. Ekonomik büyüme, daha geniş kapsamlı ekonomik gelişmelerde çeşitli nedenlerle çalışmak için heyecan verici bir alandır. $\mathrm{Bu}$ nedenlerden birincisi, eldeki soruların büyük ilgisine ve

\footnotetext{
* Sorumlu yazar/Corresponding author
}

e-posta: akay.unvan@gmail.com 
önemine rağmen, alanın hala çok fazla bilinmeyen ve çok büyük zorluğunun olmasıdır. İkincisi, Kuznets'in vurguladığı gibi ekonomik büyümenin çok yönlü bir yapıya sahip olmasıdır (Kuznets, 1967). Bu sadece toplam çıktının büyümesi değil, aynı zamanda bir ekonominin sektörel yapısından demografik ve coğrafi yapısına ve belki de daha önemlisi tüm sosyal ve kurumsal dokusuna temel dönüşümüyle ilgilidir. $\mathrm{Bu}$ süreçler doğal olarak ekonomik büyüme ve kalkınmaya ekonominin diğer birçok alanından çok daha bütünsel bir yaklaşım gerektirir. $\mathrm{Bu}$ durum, zengin bir dizi soruya ve ekonomik büyümenin temel sorularına çeşitli yeni yaklaşımlara yol açmaktadır. Üçüncüsü, ekonomik büyüme teorisi aynı zamanda ekonomi içinde özel bir yere sahip olmasıdır. Çünkü mikro ve makroyu heyecan verici bir şekilde birleştirmektedir. Ekonomik büyüme, doğası gereği, toplum ve makro sonuçlarla ilgilidir. Bununla birlikte, makroekonominin diğer birçok alt alanının aksine, ekonomik büyüme çalışması sıkı bir şekilde mikroekonomik temellere dayanmaktadır. Sonuncu neden ise daha fazla araştırmacı büyüme ve gelişme alanındaki yeni ampirik soruları araştırmaya yöneldiğinden, ekonomik büyüme büyük ölçüde ampirik bir alandır. Ekonomistler son zamanlarda ekonomik büyüme sürecini destekleyen mikroekonomik ilişkilerin araştırılmasına çok fazla enerji ve zengin veri getirmişlerdir (Acemoglu, 2012: 546).

Ekonomik büyüme oran1; ihracat, ithalat, enflasyon, faiz oranları, gayri safi milli hasıla, kişi başına düşen gelir, politik kararlar, ülke parasının diğer para birimleri karşısındaki değeri, işsizlik oranı, dış borç ve merkez bankası rezervleri gibi pek çok durum ve göstergeden etkilenmektedir. Kişi başına düşen gelir için daha düşük başlangıç seviyesine sahip ülkelerin daha hızlı bir ekonomik büyüme yaşaması beklenebilir (Henisz, 2000: 20). Bunu destekleyen temel teori, Solow (1956) ve Koopmans (1965) tarafindan sunulan teoridir. Bu teoride belirli bir seçim seti ve çevresel değișkenler için kiși bașına sabit bir durum seviyesi vermektedir. Ekonomideki veya hükümetteki bireyler, kişi başına üretimin uzun dönemli istikrarlı hal seviyesini artıracak (veya çevresel şoklar meydana gelmesi durumunda) seçimler yaparsa, çıtı seviyeleri uzun bir geçiş dönemi boyunca yeni istikrarlı durumlarına yakınlaşağı ifade edilmektedir. $\mathrm{Bu}$ durum belirli bir yıldaki büyüme oranlarının çevresel değişkenlerin yanı sıra bireysel ve hükümet seçim değişkenlerinin seviyelerine bağlı olacağı anlamına gelmektedir. $\mathrm{Bu}$ varsayımlara dayanarak, kişi başına düşen gelirde daha düşük başlangıç seviyesine sahip ülkelerin daha hızlı bir ekonomik büyüme yaşayabileceği söylenebilir. Ayrıca ekonomik büyümeyi etkileyen faktörlerden birisi, günümüzün önemli finansman kaynaklarından biri olan dış borçlanmadır. Dış Borçlanma, ekonomik gelişmelerini sürdürebilmeleri için yeterli gelir ve tasarruf düzeyine sahip olmayan gelişmekte olan ülkeler açısından ayrıca önem taşımaktadır (Kutlu vd., 2016: 229). Borçlanılan paranın kullanılma şekli, ekonomik büyüme üzerinde şüphesiz bir etkiye sahiptir.

Ekonomik büyüme ile ilişkili olan bir başka unsur; borsa ve bankacılık sektörleri ve bu sektörlerin gelişimidir. Bu ilişkiyi değerlendirmek için ilk olarak; borsa likiditesi, büyüklüğü, oynaklığı ve dünya sermaye piyasalarıyla entegrasyonunun ampirik göstergeleri gerekmektedir. Bu göstergelerin her birinin eksiklikleri olmasına rağmen, çeşitli tedbirlerin kullanılması, borsa gelișimi ile ekonomik büyüme arasındaki bağların tek bir gösterge kullanılmasından daha zengin bir tablo sunmaktadır. İkinci olarak, bankacılık gelişiminin ampirik göstergesi bu değerlendirme için gereklidir. Üçüncü ve son olarak, kişi başına reel GSYH büyümesi, kişi başına reel fiziksel sermaye stoku büyümesi, verimlilik artışı ve özel tasarrufların GSYH'ye oranı; ekonomik büyüme ve borsabankacılık sektörlerinin gelişimi arasındaki ilişkiyi açıklayan göstergelerdir (Levine vd., 1998: 541).

Son yıllarda Türkiye ekonomisi, enflasyon, işsizlik, cari açık ve ekonomik büyüme arasında sıkışmış durumdadır. $\mathrm{Bu}$ durum, Türkiye ekonomisi açısından paradoksal bir durum ortaya çıkarmış olup, ekonomi politikası yapıcıların bu sorunu aşmaları pek mümkün olmamıştır. Ekonomik büyümeyi arttırmak ve işsizliği azaltmak için genişletici para ve maliye politikaları uygulanmaya başlandığında, cari açık ve enflasyon artmakta, cari açı̆̆ı ve enflasyonu düşürmek için sıkılaştırıcı para ve maliye politikaları uygulandığında ise ekonomik büyüme, potansiyel büyüme oranının altına inmekte ve işsizlik yükselmeye başlamaktadır (Göçer vd., 2016: 37). Bu durum ise ekonomik büyümenin istikrarsızlaşmasına yol açmakta ve bu paradoksal durumun çözüme ulaştırılamaması potansiyel bir ekonomik krizi tetiklemektedir. $\mathrm{Bu}$ istikrarsızlığın nedenleri olarak; finansal piyasalardaki yetersizlikler, kurumsal sorunlar, yüksek reel faiz oranları ve yüksek enflasyon oranları da sayılabilir. Türkiye, dönem dönem yüksek ekonomik büyüme oranlarına ulaşmış olsa da, büyümede meydana gelen düşüşler ve inişli çıkışlı büyüme grafiği büyümenin istikrarlı bir yapı sergilemediğini gözler önüne sermektedir. (Yardımc1, 2006: 112).

Şekil 1'de 2010-Q1 ve 2019-Q3 dönemleri arasında Türkiye'nin ekonomik büyüme oranlarına ait grafik verilmiştir. Bu grafiğe göre son 9 yılda ekonomik büyüme oranı inişli çıkışlı, istikrarsız bir durum göstermektedir. 2010 yılının son çeyreği ve 2017 yılının üçüncü çeyreği büyüme oranlarının en yüksek olduğu dönemlerdir. Bu durumun aksine, 2016 yılının üçüncü çeyreği ve 2018 yılının üçüncü çeyreği büyüme oranlarının en düşük olduğu dönemlerdir. Özellikle 2018 yılının üçüncü çeyreğindeki bozulma ve negatif büyüme oranı dikkat çekidir. Bunun başlıca nedeni ise bu dönemde yaşanan Türk Lirası'ndaki büyük değer kaybı olarak gösterilebilir.

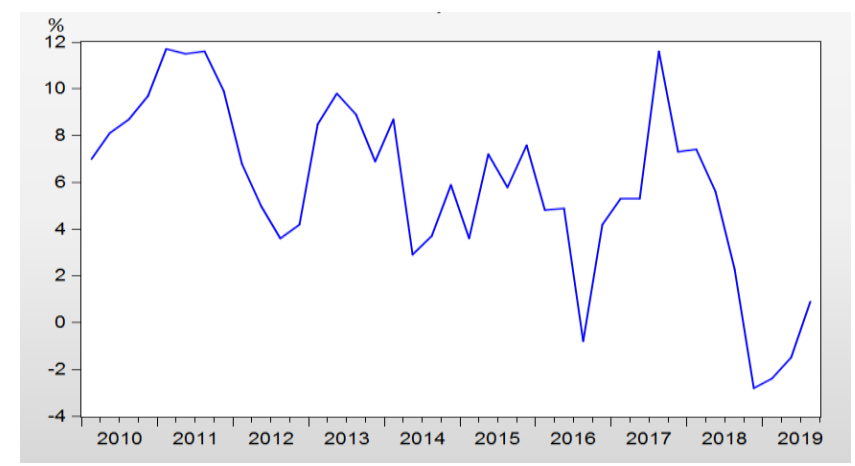

Şekil 1. Türkiye'de Ekonomik Büyüme Oranları 


\section{Literatür İncelemesi}

\subsection{Türkiye'deki Ekonomik Büyümeye Dair Literatür İncelemesi}

Erbaykal ve Okuyan (2008), bu çalışmada Türkiye'de enflasyon ile ekonomik büyüme arasındaki ilişkiyi 1987Q12006Q3 dönemlerini kapsayan veriler çerçevesinde incelemiştir. İki değiş̧en arasında eşbütünleşme ilişkisinin varlığı, test sonucunun ardından tespit edilmiştir. Oluşturulan otoregresif dağıtılmış gecikmeye bağlı (ARDL) modeller sonucunda istatistiksel olarak anlamlı uzun vadeli bir ilişki bulunmazken, negatif ve istatistiksel olarak anlamlı kısa vadeli bir ilişki bulunmuştur. Nedensellik testi sonucunda ise enflasyondan ekonomik büyümeye nedensellik ilişkisi bulunmazken, ekonomik büyümeden enflasyona bir nedensellik ilişkisi bulunmuştur. Ayrıca, istikrarlı ve sürdürülebilir bir büyüme için maliyet istikrarını sağlayan makroekonomik politikaların önemli olduğu belirtilmiştir.

Yamak ve Tanrı̈ver (2009), bu çalışmada getiri farkının ekonomik büyüme oranlarını etkileyip etkilemediğini, etkilemişse de hangi yönde etkilediğini Türkiye örneği için test etmeyi amaçlamıştır. Çalışmada, 1990-2006 dönemine ait üçer aylık reel GSYH ile 3 ve 12 aylık vadeli mevduat faiz oranları kullanılmıștır. Regresyon denklemlerine, elde edilen sonuçları kuvvetlendirmesi için kontrol değişseni olarak enflasyon oranı da dahil edilmiştir. Ayrıca çalışmada, reel GSYH büyüme oranlarındaki değişmeler yalnızca getiri farkı ile değil kısa ve uzun vadeli faiz oranı olarak tanımlanan 3 ve 12 aylık faiz oranlarının her biri ile açıklanmaya çalışılmıştır. Yapılan analizler sonucunda, Türkiye'de gelecek dönem büyüme oranlarını hem faiz oranları hem de getiri farkının etkilediği yönünde bulgular elde edilmiştir.

Şentürk ve Akbaş (2014), bu çalışmada, 2005:01-2012:07 döneminde Türkiye'deki ekonomik büyüme, işsizlik oranı ve enflasyon oranı arasında karşılıklı ilişkinin varlı̆̆ incelemiştir. İlk olarak serilerin durağanlıkları birim kök testleri ile sınanmıştır. Ayrıca, serilerde meydana gelen yapısal kırılmaları tespit etmek amaciyla yapisal kırılmalı birim kök testi gerçekleștirilmiş̧tir. Son olarak, seriler arasındaki nedensellik ilişkisinin belirlenmesi için bootstrap nedensellik testleri gerçekleştirilmiştir. Sonuç olarak ekonomik büyüme ile diğer değişkenler arasında nedensellik ilişkisi bulunmadığı fakat sanayi üretim endeksi ve enflasyon oranı ile işsizlik oranı arasında çift yönlü nedensellik ilişkileri tespit edilmiştir.Kutlu ve Yurttagüler (2016), çalışmalarında, Türkiye'de net dış borç stoku ile ekonomik büyüme arasındaki ilişkiyi 1998:01-2014:02 dönemi için Granger nedensellik testi ile analiz etmişlerdir. Yapılan analizler sonucunda dış borçtan ekonomik büyümeye doğru tek yönlü bir nedensellik ilişkisinin varlığını destekleyen bulgular elde etmişlerdir.

Ozpence (2016), vektör hata düzeltme ve Granger nedensellik analizini kullanarak 2003:1-2015:4 dönemi verileriyle, Türkiye'de ekonomik büyüme ve enflasyon arasındaki ilişkiyi araştırmıştır. Nedensellik analizi sonuçlarına göre, ekonomik büyümeden enflasyona doğru tek yönlü bir nedensellik ilişkisinin varlığı tespit edilmiştir. Topcu (2017), bu çalışmasında, Türkiye'de ekonomik büyüme ile enflasyon arasındaki nedensellik ilişkisini 2006:1-2017:2 dönemini içeren güncel verilerle incelemiștir. Ekonomik büyüme ile enflasyon arasındaki ilişki incelenirken kurulan modele, kontrol değişkeni olarak emek değişkeni de dahil edilmiștir. Eşbütünleșme analizinden elde edilen bulgular, ekonomik büyüme ile enflasyon arasında uzun dönem bir ilişkinin bulunmadığını ortaya koymuştur. Granger nedensellik analizinden elde edilen bulgular ise, Türkiye'de ekonomik büyümeden enflasyona doğru tek yönlü bir nedensellik ilişkisinin olduğunu göstermiştir. Ayrıca nedensellik analizi bulguları, ekonomik büyüme ile emek arasında çift yönlü nedensel bir ilişkinin olduğunu ortaya koymuştur.

Fatih (2019), yapmış olduğu bu çalışmada ekonomik büyüme, kısa vadeli sermaye hareketleri ve döviz kuru arasındaki teorik ve ampirik ilişkiyi incelemiştir. Ocak 2005-Ocak 2018 dönemine ait ÜFE bazlı reel efektif döviz kuru, sanayi üretim endeksi ve kısa vadeli sermaye hareketlerinin göstergesi olarak portföy yatırımı birer değişken olarak kullanılmıştır. Yapılan analizler sonucunda, incelenen dönemde Türkiye ekonomisi portföy yatırımlarının, ekonomik büyüme göstergesi olarak kabul edilen sanayi üretim endeksi üzerinde anlamlı etkisinin olmadığı ve reel döviz kurunun, sanayi üretimi üzerinde negatif etkisinin olduğu tespit edilmiştir. Bu sonuçlara göre istikrarlı bir üretim artışı ve ekonomik büyüme hedefi için kısa vadeli sermaye hareketi (KVSH) yerine başarılı kur politikaları belirlenip uygulanmasının daha önemli olacağı öngörülmüştür.

Karabulut (2019), Türkiye ekonomisi için 2003Q1-2018Q1 döneminde ekonomik büyüme ve enflasyon arasındaki ilişkiyi analiz etmiştir. Yapılan Granger nedensellik testi sonucunda $\% 5$ anlamlıl1k seviyesinde GSYH'nın, enflasyonun nedeni olduğu sonucuna ulaşılmış ancak enflasyondan GSYH'ya doğru bir nedensellik ilişkisi tespit edilememiştir. Daha sonra değişkenler arasında eşbütünleşme analizi yapılmış ancak herhangi bir eşbütünleşmeye rastlanılmamıştır. Bu sonuca göre, GSYH ve enflasyon arasında uzun dönemli bir ilişkinin olmadığını ve serilerin uzun dönemde birbirinden bağımsız hareket ettiği ifade edilmiştir.

Toker ve Gürel (2019), bu çalışmada, Türkiye ekonomisi için ekonomik büyüme ile enflasyon arasındaki ilişkiyi analiz etmiştir. Mundell-Tobin etkisi olarak adlandırılan yaklaşıma göre; ekonomide enflasyon oranlarının arttığı dönemlerde, elde para tutmanın maliyeti de artmaktadır. Bu etkiye dayanılarak, bireyler reel gelir düzeylerini korumak için sermaye birikimine yöneleceği ve bu durumda da yatırımların artmasıyla birlikte ekonomik büyümenin pozitif yönde artış göstereceği ifade edilmiştir. Bu ilişkinin tespiti amacıyla, 1980-2016 dönemleri için enflasyon oranı, gayri safi sabit sermaye yatırımları ve ekonomik büyüme ilişkisi ARDL sınır testi yöntemi ile araştırılmıştır. Elde edilen bulgulara göre, enflasyonun arttığ dönemlerde ekonomik büyümenin azaldığı belirlenmiş̧tir. Bu sonuçlara göre; Türkiye'de 1980-2016 dönemleri arasında MundellTobin etkisinin geçerli olmadığı ifade edilmiştir. 


\subsection{Yurtdışında Ekonomik Büyüme Üzerine Yapılan Çalışmalar İçin Literatür İncelemesi}

Marquis ve Reffert (1995), Amerika Birleşik Devletleri (ABD)'nin 1959:1-1991:6 dönemindeki aylık verilerini kullanarak yaptıkları çalışmada, enflasyonun $\% 5$ seviyesinden \%0 seviyesine inmesi durumunda ABD’deki ekonomik büyümenin $\% 0,68$ oranında artacağını belirlemişlerdir.

Andres ve Hernando (1999), yaptıkları çalışmada iki önemli sonuç bulmuşlardır. Birincil sonuç, enflasyon ile büyüme arasında negatif bir ilişki olmasıdır ve bu ilişki Organisation for Economic Co-operation and Development (OECD)'1 oluşturan sanayileşmiş ülkelerde bile geçerlidir. Bulunan ikincil sonuç ise enflasyon düşük olduğunda enflasyon etkisinin daha büyük olmasıdır; yani, büyüme üzerindeki olumlu etki, enflasyon $\% 5$ 'ten $\% 4$ 'e düştüğünde, \%20'den \%19'a düştüğünden daha büyüktür. Elde edilen bu sonuçlar neticesinde, merkez bankalarına fiyat istikrarı para politikasının birincil uzun vadeli hedefi olması gerekliliği önerilmiştir.

Mallik ve Chowdhury (2001), dört Güney Asya ülkesi (Bangladeş, Hindistan, Pakistan ve Sri Lanka) için enflasyon ve GSYH büyümesi arasındaki ilişkiyi incelemiştir. International Monetary Fund (IMF) Uluslararası Finansal İstatistiklerinden toplanan y1llık veriler kullanılarak eşbütünleşme ve hata düzeltme modellerinden deneysel kanıtların bir karşılaştırması elde edilmiştir. Çalışmadaki dört ülke için de GSYH büyüme oranı ile enflasyon arasında uzun vadeli pozitif bir ilişki olduğuna dair kanıtlar bulunmuştur. Yazarlar, orta dereceli enflasyonun büyümeye yardımcı olabileceğini, ancak hızlı ekonomik büyümenin yüksek enflasyon olarak geri dönebileceğini söylemişlerdir.

Ayyoub, Chaudhry ve Farooq (2011), bu çalışmanın temel amacinı Pakistan ekonomisinde enflasyonun GSYH büyümesi üzerindeki etkisini ampirik olarak analiz etmek olarak belirlemiştir. $\mathrm{Bu}$ amaçla 1972-73 ve 2009-10 dönemine ait yıllık zaman serisi verileri alınmış ve EKK yöntemi kullanılarak analizler yapılmıştır. Analizler sonucunda Pakistan ekonomisinde negatif ve anlamlı bir enflasyon büyüme ilişkisinin var olduğu görülmüştür. Çalışmanın sonuçları, hüküm süren enflasyonun belirli bir eşik seviyesinden sonra ekonominin GSYH büyümesine zararlı olduğunu göstermektedir. Tanımlayıcı ve ekonometrik analizler temelinde, politika yapıcılara ve Pakistan Devlet Bankası'na enflasyonu \%7 seviyesinin altına düşürmesi için politikalar üretmesi önerilmiştir.

Kasidi ve Mwakanemela (2013), enflasyonun Tanzanya'daki ekonomik büyüme üzerindeki etkisini incelemiştir. Bu amaçla 1990-2011 dönemine ait zaman serisi verileri kullanılmıştır. Korelasyon katsayısı ve ortak entegrasyon tekniği enflasyon ile GSYH arasındaki ilişki kurulmuştur ve GSYH'daki değişimin genel fiyat seviyelerindeki değişikliklere tepki verme derecesini ölçmek için esneklik katsayısı uygulanmıştır. Sonuçlar, enflasyonun ekonomik büyümeyi olumsuz etkilediğini göstermiştir. Çalışma ayrıca, enflasyon ile ekonomik büyüme arasında eşbütünleşme olmadığını ortaya koymuştur. Bir başka deyişle, Tanzanya'da enflasyon ve ekonomik büyüme arasında uzun vadeli bir ilişki mevcut değildir.

Adeniran, Yusuf ve Olatoke (2014), bu çalışmada 19862013 yılları arasında döviz kuru, enflasyon ve faiz oranının ekonomik büyümeye etkisi olup olmadığını incelemiştir. Verileri test etmek için korelasyon analizi ve EKK yöntemi ile regresyon analizi yapılmıştır. Sonuç olarak, döviz kurunun ekonomik büyüme üzerinde pozitif etkiye sahip olduğunu ancak istatistiksel olarak önemli olmadığı bulunmuştur. Aynı zamanda, faiz oranı ve enflasyon oranının ekonomik büyüme üzerinde olumsuz etkisi olduğu ancak bu sonucun da istatistiksel olarak anlamlı olmadığı bulunmuştur. $\mathrm{Bu}$ nedenle Nijerya hükümetine diş ticaret dengesini korumak için ihracatı teşvik stratejileri teşvik etmesi gerektiği ve yabancı yatırımcıların ilgisini çekecek şekilde elverişli ortam, yeterli güvenlik, etkin mali ve parasal ve altyapısal kolaylıklar sağlanması gerektiği tavsiye edilmiştir.

Aslam (2016), döviz kurunun Sri Lanka'daki ekonomik büyüme üzerindeki etkisini test etmek amaciyla bu çalışmayı yapmıştır. Bu amaçla 1970-2015 dönemindeki yıllık zaman serisi verileri kullanılmıştır. GSYH, döviz kuru, enflasyon oranı ve faiz oranı gibi değişkenler dikkate alınarak EKK yönteminin kullanıldığı çoklu regresyon modeli kullanılmıştır. Çoklu regresyon modelinin sonuçlarına göre, döviz kurunun Sri Lanka'daki ekonomik büyümeyi \%1 düzeyinde olumlu etkilediği bulunmuştur.

Mukoka (2018), Zimbabwe'deki enflasyonun ekonomik büyüme üzerindeki etkisini belirlemek amaciyla 1990'dan 2017'ye kadar enflasyon ve ekonomik büyüme (GSYH) verilerini yıllık olarak kullanarak bir veri seti oluşturmuştur. EKK yöntemi ve Johansen eşbütünleşme testi sonucunda Zimbabwe'de enflasyon ve GSYH arasinda ilişki belirlenmiştir. Elde edilen sonuçlara göre, Zimbabwe hükümetine enflasyonu düşük bir oranda (tek haneli) korumaya odaklanması gerektiğini önermektedir.

\section{Veri ve Metotlar}

\subsection{Veri}

Bu çalışmada 2010-Q1 ve 2019-Q3 dönemleri arasındaki veriler kullanılmıştır. Kullanılan verilerin kaynağı, Türkiye Cumhuriyeti Merkez Bankası (TCMB) ve Türkiye İstatistik Kurumu (TÜİK)'na ait web sitelerindeki veri ve istatistik yayınlarından alınmıştır (TCMB, 2020; TÜİK, 2020). Alınan bu verilerle 5 farklı değişken oluşturulmuştur. Tüm analiz ve testler, EViews 9 programı kullanılarak bu değişkenler üzerinde uygulanmıştır.

\subsection{Metotlar}

\subsubsection{ADF Birim Kök Testi}


Belirli bir zaman içerisinde olușturulan değişkenler, zaman serileri olarak adlandırılmaktadır. Zaman serileri, birim kök içerebileceğinden her zaman doğru sonuçlar vermemektedir. Bu nedenle serilerin durağanlıklarının test edilmesi gerekmektedir. Durağanlık ise zaman serilerinin belirli bir zaman sürecinde artma veya azalmaya sahip olması ve verilerin bu zaman süreci boyunca yatay eksende dağılım göstermesidir. Yani zaman serisi durağansa, ortalaması ve varyansı zaman içerisinde değişmemektedir. Gecikmeli iki zaman serisindeki değişkenlerin kovaryansı, değişkenler arasında bulunan gecikmeye bağlıdır. (Gujarati, 2001: 713; Sevüktekin vd., 2014: 239). Ayrıca değişkenler arasında yüksek $\mathrm{R}^{2}$ (ilişki oranı) değerine sahip sahte regresyonlar da bulunabilmektedir. Değişkenlerin durağanlaştırılmasında kullanılan testlerden biri olan Augmented Dickey-Fuller (ADF) birim kök testi ile bu hatalar giderilmektedir. (Çelikkol vd., 2015: 817). ADF testi (Dickey vd., 1979, 1981) bir $Y$ bağımlı değişkeninin ilk farkının gecikmeli seviyesinde, eksojen değişken(ler) ve k gecikmeli ilk farklarının alınmasını gerektirir. Denklem (1)'de görüldüğü üzere ADF birim kök testine ait denklem şu şekildedir:

$\Delta Y_{t}=a+\beta T+p Y_{t-1}+\sum_{i=1}^{k} \gamma_{i} \Delta Y_{t-i}+e_{t}$

Burada " $Y_{t}$ " t.dönemdeki değişkeni, " $T$ " bir zaman trendini, " $\Delta$ " fark operatörünü, " $e_{t}$ " ortalama sifir ve varyans $\sigma^{2}$ iken bir hata terimi bozukluğunu ve " $k$ " ADF denklemlerindeki farklılıkların gecikmesini sayısını ifade etmektedir.

\subsubsection{En Küçük Kareler Yöntemi ile Regresyon}

En Küçük Kareler (EKK) yöntemi ile regresyon, bir veya daha fazla bağımsız değişken ile bağımlı değişken arasındaki ilişkiyi, bağımlı değişkenin gözlemlenen ve tahmin edilen değerleri arasındaki farkın kareler toplamını en aza indirgeyerek tahmin eden istatistiksel bir analiz yöntemidir (What-when-how, 2020). EKK, normal dağılıma sahip verilere dayanır fakat bu durum her zaman gerçekleşmez. Ayrıca EKK yönteminin diğer bir dezavantajı, hata teriminin karesi nedeniyle aykırı değerlere duyarlı olmasıdır. (Foussier, 2010). Bağımlı bir değişkeni " $Y$ " öngören ve sadece bir bağımsız değişkeni " $X$ " içeren basit bir EKK regresyon modeli, denklem (2) ile ifade edilir.

$Y=a+b X+\varepsilon$

Burada " $a$ ", düz çizginin Y ekseniyle nerede kesiştiğini gösteren kesiştir. " $b$ ", düz çizginin diklik derecesini gösteren eğimdir. " $\varepsilon$ " ise hatayı temsil etmektir. Ayrıca, en iyi çizgi (ilişki), En Küçük Kareler Hatalarının (EKKH) toplamidir (Darity, 2008). Bu toplam denklem (3)'teki formül ile bulunmaktadır.

$$
E E K H=\Sigma(Y i-\hat{Y})
$$

$Y_{i}=i$ bağımlı değişkeni ve $i=1, \ldots, n$ olmak üzere bağımlı değişkenin tahmini denklem (4)'teki gibi elde edilmektedir.

$\hat{Y}=(\Sigma Y i) / n$

\subsubsection{COVRATIO}

Regresyon modellerinde bazen aykırı gözlemler bulunabilir. $\mathrm{Bu}$ gözlemlerin tespiti için kullanılan yöntemlerden birisi, COVRATIO olarak adlandırılmaktadır. İlk olarak, doğrusal regresyon modelleri için Belsley vd. (1980), kovaryans matrislerinin belirleme oranına göre aykırı gözlemlerin tanımlanmasını önermişlerdir. $\mathrm{Bu}$ öneriden sonra ise COVRATIO yöntemini geliştirmişlerdir.

$\operatorname{COVRATIO}_{(-j)}=\frac{\left|\operatorname{COV}_{(-j)}\right|}{|\operatorname{COV}|}$

Denklem (5)'te verilen formülde $C O V$, tüm veri seti için kovaryans matrisidir ve $\operatorname{COV}_{(-j)}$, j. satır hariç tutularak azaltılmış veri seti için kovaryans matrisidir. $3 p / n$ kritik değeri ile karşılaştırılacak test istatistiği $\mid$ COVRATIO ${ }_{(-j)}-$ 1) formülü ile bulunmaktadır. Burada " $p$ " tahmini katsayıların sayısı ve " $n$ " örneklem büyüklüğüdür. Hesaplanan test istatistiği, belirtilen kritik değerden büyük ise test edilen gözlem, aykırı değer olarak adlandırılabilir (Hussin vd., 2012: 208-209).

\subsubsection{DFFITS}

Belsley vd. (1980) tarafindan önerilen gözlem silmeye dayalı olan DFFITS $_{\mathrm{i}}$ istatistiği, i.gözlemin silinmesiyle bu gözlemin tahmin değerleri üzerinde yaptığı etkiyi inceleyen bir tanı yöntemidir (Acarlar, 2011: 107). Verinin tümünden elde edilen regresyon katsayılarıyla hesaplanan i.gözleme ilişkin tahmin değeri " $\hat{y}_{i}$ ", veriden i.gözlemin silinmesiyle elde edilen regresyon katsayılarıyla hesaplanan i.gözleme ilişkin tahmin değeri " $\hat{y}_{(i)}$ " ve dönüşüm matrisinin köşegen ögeleri $h_{\text {ii }}$ olmak üzere $i$. gözlem için DFFITS şu şekilde bulunmaktadır:

$\operatorname{DFFITS}_{i}=\frac{\hat{y}_{i}-\hat{y}_{i(i)}}{s_{(i)} \sqrt{h_{i i}}}, i=1,2,3, \ldots, n$

Burada " $\mathrm{s}_{(\mathrm{i})}$ " ise denklem (7)'deki gibi hesaplanır (Hadi vd.,1993).:

$S_{i}^{2}=\frac{A K T_{(i)}}{n-p-2}$

Belsley vd. (1980), bu istatistik için kritik değeri $2 \sqrt{\mathrm{p} / \mathrm{n}}$ olarak önermişlerdir. Bu kritik değere göre; $\mid$ DFFITS $_{\mathrm{i}} \mid>$ $2 \sqrt{\mathrm{p} / \mathrm{n}}$ koşulunu sağlayan gözlemler, aykırı gözlem olarak nitelendirilmektedir. Burada " $n$ " gözlem sayısını, " $p$ " ise parametre sayısını belirtmektedir.

\subsubsection{Kantil Regresyon}

Koenker ve Bassett (1978) tarafindan ortaya konulan kantil regresyonda, koşullu kantil fonksiyonların tahminine genişletmek amaçlanmaktadır. $\mathrm{Bu}$ yöntemde Tukey'in üç ortalamasını çeyreklere ağırlık olarak $0,25,0,50$ ve 0,75 kantil değerleri olarak atayan bir prototip kullanılmaktadır (Koenker, 1984). Kantil regresyon, bağımlı değişkeninin koşullu dağılımının seçilen kantilleri için geliştirilen bir yöntemdir. EKK yöntemi ile regresyon modelinin aksine hata varyansının homojenliği ve hataların dağılımı hakkında herhangi bir varsayımı sağlama koşulu yoktur (Yavuz vd., 2017). Kantil regresyon tahminleri, veri setindeki aykırı gözlemlerin varlığına karşı EKK yöntemine göre daha sağlamdır. Ancak, belirtildiği gibi, kantil regresyonu kullanmanın en önemli mantığı, bağımlı ve bağımsız bir değişken arasındaki ilişkinin daha eksiksiz ve net şekilde ölçülebilmesidir (Conyon vd., 2017: 3-4). 
Kantil regresyon, medyan fonksiyonunu tahmin etmek için mutlak hataların toplamını azaltan medyan tahmincisini kullanmaktadır. $\mathrm{Bu}$ yöntemde tahminler, kullanılan kantil değerlerinin işlevi olduğu mutlak hataların asimetrik ağırığının azaltılmasıyla yapılmaktadır. Başka bir deyişle, kantil değerlerine sahip bir kantil regresyon modelinin bir optimizasyon problemi olduğu söylenebilir (Maiti, 2019: 4).

Kantil regresyon modelinin matematiksel formu şu şekildedir:

$y_{i}=x_{i}^{\prime} \beta_{\theta}+\mu_{\theta i}, \quad 0<\theta<1$

Quant $_{\theta}\left(y_{i} \mid x_{i}\right)=x_{i} \beta_{\theta}$

$\mathrm{Bu}$ matematiksel formda " $x$ ", açıklayıcı değişkenlerin vektörünü; " $y$ ", açıklanan değişkeni; " $\mu$ ” ise koşullu kantil dağılımı sıfira eşit olan rastgele hata terimidir. uant $_{\theta}\left(y_{i}\right)$, açıklanan değişkenin $\theta$. kantilidir. $\beta_{\theta}$ 'ın tahmini, kantil regresyon tahmincisini belirtir ve aşağıdaki formül ile belirtilir:

$\min \sum_{y_{i} \geq x_{i}^{\prime} \beta} \theta\left|y_{i}-x_{i}^{\prime} \beta\right|+\sum_{y_{i}<x_{i}^{\prime} \beta}(1-\theta) y_{i}-x_{i}^{\prime} \beta$

Burada $\theta$ farklı değerlere eşit olduğunda, farklı parametre tahminleri elde edilmektedir. Ortanca regresyon olarak tanımlanan özel durum, $\theta=0,5$ şartı altında bir kantil regresyon örneğidir (Xu vd., 2018: 112).

Tablo 2. Tanımlayıcı İstatistikler

\begin{tabular}{ccccccc}
\hline & BUYUME & DBORC & RDOVIZ & RFAIZ & TUFE \\
\hline Ortalama & 5,8820 & 382863,9 & 112,1059 & 0,7926 & 9,8423 \\
\hline Medyan & 5,9000 & 402542,0 & 115,4500 & 0,5616 & 8,7600 \\
\hline Maksimum & 11,7000 & 465724,0 & 136,3300 & 2,8784 & 22,300 \\
\hline Minimum & $-2,8000$ & 265642,0 & 75,3900 & 0,0393 & 4,3400 \\
\hline Gözlem Sayıs1 & 39 & 39 & 39 & 39 & 39 \\
\hline
\end{tabular}

\subsection{Korelasyon (İlişki) Matrisi}

Bir korelasyon matrisi, matristeki çapraz elemanların birbirine eşit olduğu $\mathrm{m}$ değişkenleri arasındaki ilişkiyi açıklamaktadır. Varyans-kovaryans matrisinden elde edilen karesel, simetrik bir $\mathrm{m}_{\mathrm{x}} \mathrm{m}$ boyutlu matristir. $\mathrm{Bu}$ matrislerin her ikisi de benzer bilgiler içerir, fakat korelasyon matrisi daha basit ve açıklayıcı olduğundan matristeki değişkenleri birbirleriyle ilişkilendirmeyi kolaylaştırmaktadır (Horn ve Johnson, 1985). Korelasyon matrisinde köşegen değerleri

\section{Bulgular}

\subsection{Değişkenler}

Analizlerde kullanılacak olan 5 farklı değişkenler için kullanılan kısaltmalar ve değişkenlere ait tanımlar Tablo 1'deki gibi verilmiştir. Bu tanımları içeren değişkenler oransal veya sayısal değerlerden oluşturulmuş gözlemleri içeren değişkenlerdir. Ayrıca analizlerde bağımlı değişken olarak kullanılacak olan BUYUME değişkeni reel bir olgudur. Bu nedenle nominal olmayan, kısa vadeli olması nedeniyle yatırımcılar tarafindan en çok tercih edilen 2 yıllık tahvillerin faiz oranları kullanılarak elde edilen reel faiz oranı (RFAIZ) ve TÜFE bazlı reel efektif döviz kuru (RDOVIZ) birer değişken olarak kullanılmıştır. Kullanılan diğer değişkenler ise literatür çalışmalarında sıklıkla tercih edilen değişkenlerdir.

Tablo 1. Değişkenlerin Tanımı

\begin{tabular}{cc}
\hline Değişkenler & Değişkenlerin Tanımı \\
\hline BUYUME & Ekonomik Büyüme Oranı \\
\hline DBORC & Dış Borç Stoku (Milyon \$) \\
\hline RDOVIZ & TÜFE Bazlı Reel Efektif Döviz Kuru \\
\hline RFAIZ & Reel Faiz Oranı \\
\hline TUFE & Tüketici Fiyatları Endeksi (Enflasyon) \\
\hline
\end{tabular}

\subsection{Tanımlayıcı İstatistikler}

Tanımlayıcı istatistikler, o değişkendeki gözlemlere ait bazı bilgiler vermekle beraber, değişkenin dağılımı hakkında bilgiler de içermektedir. Tablo 2'de çalışmada kullanılan değişkenlere ait çeşitli tanımlayıcı istatistikler verilmiştir.

Tablo 3. Değişkenler Arası Korelasyon Değerleri

\begin{tabular}{cccccc}
\hline & BUYUME & DBORC & RDOVIZ & RFAIZ & TUFE \\
\hline BUYUME & 1,0000 & sim. & sim. & sim. & sim. \\
\hline DBORC & $-0,5200$ & 1,0000 & sim. & sim. & sim. \\
\hline RDOVIZ & 0,5488 & $-0,7960$ & 1,0000 & sim. & sim. \\
\hline RFAIZ & $-0,6726$ & 0,6938 & $-0,9263$ & 1,0000 & sim. \\
\hline TUFE & $-0,6904$ & 0,5016 & $-0,7984$ & 0,9141 & 1,0000 \\
\hline
\end{tabular}


Not: Tabloda “sim.” kısaltması ile gösterilen gözeler, köşegene göre simetriktir.

\subsection{ADF Testi}

Çalışmada kullanılan değişkenler zamana bağlı periyodik değişkenler olduğu için zaman serisi olarak tanımlanmaktadır. Zaman serilerinde yapılacak analizlerde ilk önce durağanlık durumuna bakılması gerekmektedir. Durağan olmayan değişkenler hatalı sonuçlara neden olacağından durağanlaştırma işleminin yapılması gerekmektedir. $\mathrm{Bu}$ amaçla, ADF testi ile değişkenlerin durağanlıkları test edilmiştir. DBORC ve TUFE değişkenlerine ait veriler mutlak rakam olarak kullanıldıklarından dolayı, bu iki değişkene ait verilere öncelikle logaritmik dönüşüm yapılmıştır. Kullanılan değişkenler trend içermediğinden, sadece sabit kaysayı içerme koşuluna göre bu test yapılmıştır. Değiş̧kenlerin 1.dereceden farkı alındığında, tüm değişkenlerin durağanlaştığı belirlenmiștir. Yapılan bu durağanlaştırma işlemi sonrası Tablo 4'teki tüm değişkenlerin p-değerleri, 0,05 anlamlılık değerinden küçük olduğu için aşağıda verilen $\mathrm{h}_{1 \mathrm{a}}$ yokluk hipotezi reddedilecektir. Bu yüzden tüm değişkenlerin durağan olduğu ve birim köke sahip olmadığ 1 söylenebilir. Durağanlaştırılmış bu değişkenler, yapılacak diğer analizlerde kullanılacaktır.

$\mathrm{H}_{1 \mathrm{a}}: \mathrm{p}=0$ (Değişken durağan değildir ve birim köke sahiptir)

$\mathrm{H}_{1 \mathrm{~b}}$ : $\mathrm{p} \neq 0$ (Değiş̧ken durağandır ve birim köke sahip değildir)

Tablo 4. ADF Testi

\begin{tabular}{ccccc}
\hline $\begin{array}{c}\text { Durağanlık } \\
\text { Durumu }\end{array}$ & Orjinal Değişkenler & \multicolumn{2}{c}{$\begin{array}{c}\text { 1.Dereceden } \\
\text { Durağanlaştırılanlar } \\
\text { Değişkenler }\end{array}$} \\
\hline Değişkenler & t-İstatistiği & p-değeri & t-İstatistiği & p-değeri \\
\hline BUYUME & $-2,1789$ & 0,2169 & $-5,5369$ & $0,0001^{*}$ \\
\hline DBORC & $-2,7767$ & 0,0711 & $-5,2883$ & $0,0001^{*}$ \\
\hline RDOVIZ & $-0,6541$ & 0,8461 & $-5,7880$ & $0,0001^{*}$ \\
\hline RFAIZ & $-1,0603$ & 0,7213 & $-4,5132$ & $0,0010^{*}$ \\
\hline TUFE & $-1,5712$ & 0,4872 & $-5,6382$ & $0,0001^{*}$ \\
\hline
\end{tabular}

Not: “*” ile işaretlenmiş p değerleri istatistiksel olarak anlamlıdır.

\subsection{EKK Yöntemi ile Regresyon}

EKK yöntemi ile kurulan regresyon modelinde bağımlı değişken " $Y$ " üzerinde, bağımsız değişkenlerin etkisi görülmektedir.

Tablo 5'te BUYUME1 değişseninin bağımlı değişken olduğu EKK yöntemi ile kurulan bir regresyon modelinin sonuçları verilmiștir. Buna göre, BUYUME1 değişkeni üzerinde RDOVIZ1 değişkeninin -0,148391'lik, TUFE1 değişkeninin ise $-4,264171^{\prime}$ lik bir negatif etkisi vardır. Bir başka deyişle, BUYUME1 değişkenini RDOVIZ1 değişkenindeki 1 birimlik artış $-0,148391$ birim; TUFE1 değişkenindeki 1 birimlik artış ise $-4,264171$ birim azaltmaktadır. Ayrıca modelin $\mathrm{R}^{2}$ değeri yani modeldeki değiş̧kenler arasındaki ilişki \%25,45'tir. İlişki katsayısının normal seviyelerden (\%60-\%70) düşük çıkmasının nedeni ise modelin farklı alanlardan değişkenler içermesi, değişkenlerin 1.dereceden farklarının alınarak durağanlaştırılması ve periyodun çeyreklik olarak alınması olarak gösterilebilir. Tablodaki p-değeri ise 0,0408 olarak bulunmuştur. Bulunan p-değeri 0,05 anlamlılık değerinden küçük olduğu için yokluk hipotezi olan $\mathrm{h}_{2 \mathrm{a}}$ : "Gözlenen noktaların regresyon çizgisi ile korelasyonu ihmal edilebilir düzeydedir. (Model önemli değildir.)" reddedilmektedir. Bir başka deyişle model önemli ve istatistiksel olarak anlamlıdır. Bu sonuçlara göre Tablo 5'teki regresyon modeli şu şekildedir:

$$
\begin{aligned}
& \text { BUYUME1 }=-0,148391 * \text { RDOVIZ1 }-4,264171 * \\
& \text { TUFE1 }
\end{aligned}
$$

Tablo 5. EKK Yöntemi ile Regresyon

\begin{tabular}{ccccc}
\hline Değişkenler & Katsayı & Standart Hata & t-İstatistiği & p-değeri \\
\hline DBORC1 & $-4,753004$ & 17,21946 & $-0,276025$ & 0,7843 \\
\hline RDOVIZ1 & $-0,148391$ & 0,081637 & $-1,817682$ & $0,0782^{* *}$ \\
\hline RFAIZ1 & $-2,844656$ & 1,730191 & $-1,644128$ & 0,1096 \\
\hline TUFE1 & $-4,264171$ & 2,422826 & $-1,759999$ & $0,0877^{* *}$ \\
\hline C & $-0,114191$ & 0,482603 & $-0,236615$ & 0,8144 \\
\hline \multicolumn{7}{c}{ Modele Ait İstatistikler } \\
\hline $\mathrm{R}^{2}$ & \multicolumn{4}{c}{ F-İstatistiği } \\
\hline Standart Hata & 0,2545 & p-değeri & 2,8166 \\
\hline
\end{tabular}

Not: “*” ile işaretlenen değerler \%5 anlamlılık düzeyinde, “**” ile işaretlenen değerlerse \%10 anlamlılık düzeyinde istatistiksel olarak anlamlıdir.

Not2: Değişkenlerin sonuna eklenen "1" değişkenlerin 1.dereceden durağanlaştırılmış halini ifade etmektedir.

\subsubsection{Varsaylmlar}

EKK yöntemi ile kurulan regresyon modellerinde sonuçları olduğu gibi kabul etmek yanıltıcı sonuçlar verebilmektedir. Sonuçların yanıltıcı olup olmadığının tespiti için bazı regresyon varsayımları test edilmektedir. Regresyon modelinin bu varsayımlardan birini sağlamaması, modeli geçersiz kılabilmektedir. Tablo 5'te kurulan regresyon modeli içinde bazı varsayımların uygunluğuna bakılacaktır.

\subsubsection{Normallik Varsayımı}

Modelde kullanılan verilerin normallik varsayımına uyup uymadığına ilişkin yapılan Jarque-Bera test istatistiğinin pdeğeri 0,8414 olarak bulunmuştur. Bulunan p-değeri 0,05 
anlamlılık değerinden büyük olduğu için aşağıda verilmiş olan $\mathrm{h}_{3 \mathrm{a}}$ yokluk hipotezi reddedilemez. Veriler \%95 güvenilirlik düzeyinde normal dağılıma uygun bir şekilde yayılım göstermektedir.

$\mathrm{H}_{3 \mathrm{a}}$ : \%95 güven düzeyinde veriler normal dağılıma uymaktadir.

$\mathrm{H}_{3 \mathrm{~b}}: \% 95$ güven düzeyinde veriler normal dağılıma uymamaktadır.

\subsubsection{Aykırı Gözlem İncelemesi}

Regresyon modellerine dair varsayımlardan birisi de aykırı gözlem içermemesidir. Regresyon modeli aykırı gözlem DFFITS

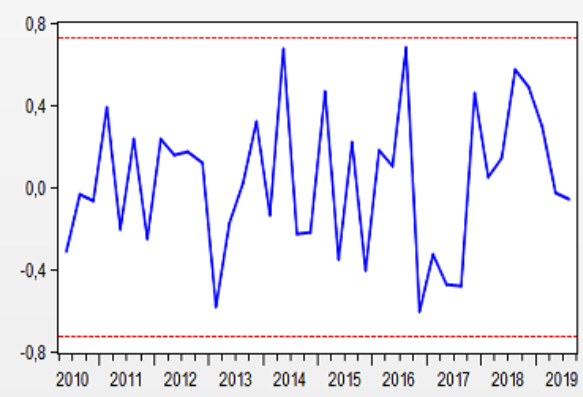

içeriyorsa, hatalı sonuçlar elde etmemek için alternatif yöntemlere geçilmesi önerilmektedir. Bu modele ait aykırı gözlem incelemesi COVRATIO ve DFFITS yöntemleri kullanılarak yapılmıştır. İnceleme sonucunda COVRATIO yöntemine göre Şekil 2'de görüldüğü üzere birkaç aykırı gözleme rastlanmıştır; bu nedenle EKK yöntemi ile regresyona alternatif bir yöntem olan kantil regresyon yöntemine geçilmesi uygun görülmüştür.

Şekil 2. DFFITS ve COVRATIO Yöntemleri ile Aykırı Gözlem İncelemesi

\subsection{Kantil Regresyon}

Kantil regresyon, EKK yöntemi ile kurulan regresyon modellerinin varsayımlardan birini veya pek çoğunu sağlamaması durumunda kullanılan alternatif bir yöntemdir. Kantil regresyonda veriler bölünerek incelenmektedir. Bunun nedeni ise verilerin dağılımında kuyruk kısımlarının da bir önem taşımasıdır. Kantil regresyonu, EKK yönteminden ayıran en önemli noktalardan birisi de budur. $\mathrm{Bu}$ analizde değişkenlerin 1.dereceden farkları alınarak 5 farklı kantil değeri için 2 farklı anlamlılık değeri incelenmiştir. İlk olarak, Tablo 6'daki 0,15 kantil değeri kullanılarak bir regresyon modeli elde edilmiștir. Bu kantil değerinde verilerin en düşük değerli \%15'lik kısmı, verilerin en yüksek değerli \%85'lik kısmından ayrılır ve bu şekilde bir model oluşturulur. Yani dağılımın sol kuyruk kısmında bir incelenme yapılmaktadır. Her değişken için gözlem değerinin 38 olması nedeniyle yorumlanabilir sayısal sonuçlar veren en küçük kantil değeri 0,15 'tir. Bu nedenle 0,15 kantil değeri kullanılmış ve \%10 anlamlılık düzeyinde $(\alpha=0,10)$ oluşturulan model sonuçları Tablo 6' da verilmiştir. Tablodaki sonuçlara göre, BUYUME1 bağımlı değişken olduğu zaman; RDOVIZ1 değişkeni, TUFE1 değişkeni ve C sabit katsayısı \%90 güvenilirlik düzeyinde istatistiksel olarak anlamlılardır. RDOVIZ1 değişkeni 0,174098'lik bir katsayıya ve TUFE1 değişkeni 6,174832'lik bir katsayıya sahip olduğundan bu iki değişkendeki her 1 birimlik artış BUYUME1 bağımlı değişkenini negatif etkilemektedir. C katsayısı da 3,035580'lik bir katsayı ile negatif etki göstermektedir. Modelin $\mathrm{R}^{2}$ değeri ise \%25,04'tür. İlişki katsayısının normal seviyelerden (\%60-\%70) daha düşük çıkmasının nedeni modelin farklı alanlardan değişkenler içermesi, değişkenlerin 1.dereceden durağanlaştırılması ve periyodun çeyreklik olarak alınması olarak gösterilebilir. Bulunan tüm modellerde bu durum geçerlidir. Ayrica bu modelin pdeğeri 0,10 anlamlılık düzeyinden küçük olduğu için $\mathrm{h}_{4 \mathrm{a}}$ yokluk hipotezi "Gözlenen noktaların regresyon çizgisi ile korelasyonu ihmal edilebilir düzeydedir (model anlamlı değildir)." reddedilmektedir. Yani modelin \%90 güvenilirlik düzeyinde istatistiksel olarak anlamlı olduğu söylenebilir.

Tablo 6. 0,15 Kantil Değerine Sahip Regresyon Modeli $(\alpha=0,10)$

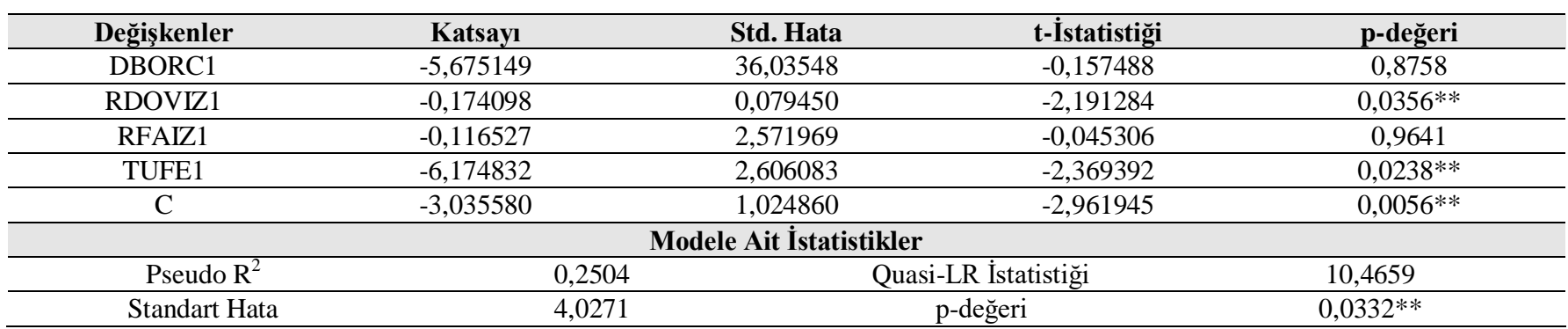

Not: ** ile işaretlenen değerleri \%10 anlamlılık düzeyinde istatistiksel olarak anlamlıdır.

0,15 kantil değeri ve $\% 5$ anlamlılık değeri $(\alpha=0,5)$ için oluşturulan model sonuçları Tablo 7'de verilmiştir. Tablodaki sonuçlara göre, yalnızca C sabit katsayısı \%95 güvenilirlik düzeyinde istatistiksel olarak anlamlılardır. C sabit katsayısı -3,035580'lik bir katsayı ile negatif etki göstermektedir. Modelin $\mathrm{R}^{2}$ değeri \%25,04'tür. Ayrıca modele ait p-değeri, 0,05 anlamlılık düzeyinden büyük olduğu için $h_{5 a}$ yokluk hipotezi "Gözlenen noktaların 
regresyon çizgisi ile korelasyonu ihmal edilebilir düzeydedir (model anlamlı değildir)." reddedilememektedir. Bu sebeple model $\% 95$ güvenilirlik düzeyinde istatistiksel olarak anlamlı değildir. Model yorumlamalarda kullanılamaz.

Tablo 7. 0,15 Kantil Değerine Sahip Regresyon Modeli $(\alpha=0,05)$

\begin{tabular}{ccccc}
\hline Değişkenler & Katsayı & Std. Hata & t-İstatistiği & p-değeri \\
\hline DBORC1 & $-5,675149$ & 38,07492 & $-0,149052$ & 0,8824 \\
\hline RDOVIZ1 & $-0,174098$ & 0,096214 & $-1,809493$ & 0,0795 \\
\hline RFAIZ1 & $-0,116527$ & 2,623356 & $-0,044419$ & 0,9648 \\
\hline TUFE1 & $-6,174832$ & 3,047391 & $-2,026268$ & 0,0509 \\
\hline C & $-3,035580$ & 1,035092 & $-2,932666$ \\
\hline \multicolumn{5}{c}{ Modele Ait İstatistikler } \\
\hline Pseudo R & \multicolumn{3}{c}{ Quasi-LR İstatistiği } \\
\hline Standart Hata & 0,2504 & p-değeri & 10,4659 \\
\hline
\end{tabular}

Not: * ile işaretlenen değerleri \%5 anlamlılık düzeyinde istatistiksel olarak anlamlıdır.

0,25 kantil değeri ve $\alpha=0,10$ için oluşturulan model sonuçları Tablo 8'de verilmiştir. Bu kantil değerinde ise verilerin en düşük \%25'lik kısmının, verilerin en yüksek \%75'lik kısmından ayrılmasıyla bir model oluşturulmaktadır. Yani dağılımın sol kuyruk kısmı incelenmektedir. Bulunan modelde TUFE1 değişkeni ve C sabit katsayısı \%90 güvenilirlik düzeyinde istatistiksel olarak anlamlılardır. TUFE1 değişkeni -6,182354'lük bir katsayıya sahiptir. $\mathrm{Bu}$ değişkendeki her 1 birimlik artış
BUYUME1 bağımlı değişkenini 6,182354 birim azaltmaktadır. C katsayısı da -1,400511'lik bir katsayı ile negatif etki göstermektedir. Modelin $\mathrm{R}^{2}$ değeri ise $\% 22,87$ 'dir. Ayrıca bu modelin p-değeri 0,10 anlamlılık düzeyinden küçük olduğu için $\mathrm{h}_{6 \mathrm{a}}$ yokluk hipotezi "Gözlenen noktaların regresyon çizgisi ile korelasyonu ihmal edilebilir düzeydedir (model anlamlı değildir)." reddedilmektedir. Yani modelin $\% 90$ güvenilirlik düzeyinde istatistiksel olarak anlamlı olduğu söylenebilir.

Tablo 8. 0 ,25 Kantil Değerine Sahip Regresyon Modeli $(\alpha=0,10)$

\begin{tabular}{ccccc}
\hline Değişkenler & Katsayı & Std. Hata & t-İstatistiği & p-değeri \\
\hline DBORC1 & $-0,127679$ & 0,091156 & $-1,400660$ & 0,1706 \\
\hline RDOVIZ1 & $-16,08372$ & 28,66358 & $-0,561121$ & 0,5785 \\
\hline RFAIZ1 & $-2,558177$ & 1,607321 & $-1,591578$ & 0,1210 \\
\hline TUFE1 & $-6,182354$ & 2,981226 & $-2,073762$ & $0,0460^{* *}$ \\
\hline C & $-1,400511$ & 0,690551 & $-2,028107$ \\
\hline \multicolumn{5}{c}{ Modele Ait İstatistikler } \\
\hline Pseudo R ${ }^{2}$ & \multicolumn{3}{c}{ Quasi-LR İstatistiği } \\
\hline Standart Hata & 0,2287 & p-değeri & $10,0507^{* *}$ \\
\hline
\end{tabular}

Not: ** ile işaretlenen değerleri \%10 anlamlılık düzeyinde istatistiksel olarak anlamlıdır.

Tablo 9'da 0,25 kantil değeri kullanılarak $\alpha=0,5$ için uygulanan kantil regresyon sonuçları verilmiştir. $\mathrm{Bu}$ sonuçlara göre, hiçbir değişken $\% 95$ güvenilirlik düzeyinde anlamlı değildir. Modelin $\mathrm{R}^{2}$ değeri ise $\% 22,87$ 'dir. Ayrıca bu modelin p-değeri, 0,05 anlamlılık düzeyinden küçük olduğu için $\mathrm{h}_{7 \mathrm{a}}$ yokluk hipotezi "Gözlenen noktaların regresyon çizgisi ile korelasyonu ihmal edilebilir düzeydedir (model anlamlı değildir)." reddedilmektedir. Böylece, modelin \%95 güvenilirlik düzeyinde istatistiksel olarak anlamlı olduğu söylenebilir.

Tablo 9. 0,25 Kantil Değerine Sahip Regresyon Modeli $(\alpha=0,05)$

\begin{tabular}{ccccc}
\hline Değişkenler & Katsayı & Std. Hata & t-İstatistiği & p-değeri \\
\hline DBORC1 & $-0,127679$ & 0,097680 & $-1,307111$ & 0,2002 \\
\hline RDOVIZ1 & $-16,08372$ & 28,94418 & $-0,555681$ & 0,5822 \\
\hline RFAIZ1 & $-2,558177$ & 1,830636 & $-1,397425$ & 0,1716 \\
\hline TUFE1 & $-6,182354$ & 3,177476 & $-1,945681$ & 0,0603 \\
\hline C & $-1,400511$ & 0,702503 & $-1,993600$ & 0,0545 \\
\hline \multicolumn{7}{c}{ Modele Ait İstatistikler } \\
\hline Pseudo R ${ }^{2}$ & \multicolumn{3}{c}{ Quasi-LR İstatistiği } & 10,1685 \\
\hline Standart Hata & 0,2287 & p-değeri & $0,0376^{*}$
\end{tabular}

Not: * ile işaretlenen değerleri \%5 anlamlılık düzeyinde istatistiksel olarak anlamlıdır.

Tablo 10'da 0,50 kantil değeri kullanılarak uygulanan kantil regresyon sonuçları verilmiştir. Bu kantil değeri, beklenen değer veya 2.çeyreklik olarak da adlandırılmaktadır. Model sonuçlarına göre, BUYUME1 değişkeni bağımlı değişkenken; yalnızca RFAIZ1 değişkeni $\% 95$ güvenilirlik düzeyinde istatistiksel olarak anlamlıdır. RFAIZ1 değişkenindeki 1 birimlik artış, BUYUME1 bağımlı değişkenini $-3,995347$ birim etkilemektedir. Modelin $\mathrm{R}^{2}$ değeri ise \%11,59 olarak bulunmuştur. Ayrıca modele ait p-değeri (0,2507), 0,10 anlamlılık düzeyinden büyük olduğu için $\mathrm{h}_{8 \mathrm{a}}$ yokluk hipotezi “Gözlenen noktaların regresyon çizgisi ile korelasyonu ihmal edilebilir düzeydedir (model anlamlı değildir)." reddedilememektedir. $\mathrm{Bu}$ nedenle, modelin \%90 
Tablo 10. 0,50 Kantil Değerine Sahip Regresyon Modeli $(\alpha=0,10)$

\begin{tabular}{ccccc}
\hline Değişkenler & Katsayı & Std. Hata & t-İstatistiği & p-değeri \\
\hline DBORC1 & $-0,164232$ & 0,103937 & $-1,580115$ & 0,1236 \\
\hline RDOVIZ1 & $-0,922241$ & 24,70212 & $-0,037334$ & 0,9704 \\
\hline RFAIZ1 & $-3,995347$ & 1,876953 & $-2,128634$ & $0,0408^{* *}$ \\
\hline TUFE1 & $-3,053167$ & 2,733036 & $-1,117134$ & 0,2720 \\
\hline C & $-0,172605$ & 0,687023 & $-0,251237$ & 0,8032 \\
\hline \multicolumn{7}{c}{ Modele Ait İstatistikler } \\
\hline Pseudo R ${ }^{2}$ & \multicolumn{3}{c}{ Quasi-LR İstatistiŏi } \\
\hline Standart Hata & 0,1159 & p-değeri & 5,3765 \\
\hline
\end{tabular}

Not: ** ile işaretlenen değerleri \%10 anlamlılık düzeyinde istatistiksel olarak anlamlıdır.

Tablo 11'de 0,50 kantil değeri kullanılarak uygulanan kantil regresyon sonuçları verilmiştir. Bu sonuçlara göre bağımlı değişkeni etkileyen, istatistiksel olarak anlamlı hiçbir bağımsız değişken bulunmamaktadır. Ayrıca modelin p-değeri 0,05 anlamlılık düzeyinden büyük olduğu için $h_{9 a}$ yokluk hipotezi "Gözlenen noktaların regresyon çizgisi ile korelasyonu ihmal edilebilir düzeydedir (model anlamlı değildir)." reddedilememektedir. Bu nedenle, modelin \%95 güvenilirlik düzeyinde istatistiksel olarak anlamlı olmadığı söylenebilir. Model yorumlamalarda kullanılamaz.

Tablo 11. 0,50 Kantil Değerine Sahip Regresyon Modeli $(\alpha=0,05)$

\begin{tabular}{ccccc}
\hline Değişkenler & Katsayı & Std. Hata & t-İstatistiği & p-değeri \\
\hline DBORC1 & $-0,164232$ & 0,112162 & $-1,464245$ & 0,1526 \\
\hline RDOVIZ1 & $-0,922241$ & 26,09538 & $-0,035341$ & 0,9720 \\
\hline RFAIZ1 & $-3,995347$ & 2,074650 & $-1,925793$ & 0,0628 \\
\hline TUFE1 & $-3,053167$ & 3,037287 & $-1,005228$ & 0,3221 \\
\hline C & $-0,172605$ & 0,727486 & $-0,237263$ & 0,8139 \\
\hline \multicolumn{7}{c}{ Modele Ait İstatistikler } \\
\hline Pseudo R & \multicolumn{3}{c}{ Quasi-LR İstatistiği } & 5,0198 \\
\hline Standart Hata & 0,1159 & p-değeri & 0,2852 \\
\hline
\end{tabular}

Not: * ile işaretlenen değerleri \%5 anlamlılık düzeyinde istatistiksel olarak anlamlıdır.

Tablo 12'de kurulan modelde 0,75 kantil değeri kullanılmıştır. $\mathrm{Bu}$ kantil değeriyle oluşturulan modellerde, veri setinde bulunan en yüksek değerli verilerin $\% 25$ 'i kalan verilerin $\% 75$ 'inden ayrılarak incelenmektedir. Model sonuçlarına göre, BUYUME1 değişkeninin bağıml değişken olduğu bu modelde yalnızca $\mathrm{C}$ sabit katsayısı $\% 90$ güvenilirlik düzeyinde istatistiksel olarak anlamlıdır. C sabit katsayısındaki 1 birimlik değişim, BUYUME1 bağımlı değişkenini 1,482952 birim etkilemektedir. $\mathrm{Bu}$ modelin $\mathrm{R}^{2}$ değeri \%11,51 olarak bulunmuştur. Fakat model ait p-değeri 0,10 anlamlılık düzeyinden büyük olduğu için $\mathrm{h}_{10 \mathrm{a}}$ yokluk hipotezi “Gözlenen noktaların regresyon çizgisi ile korelasyonu ihmal edilebilir düzeydedir (model anlamlı değildir)." reddedilememektedir. $\mathrm{Bu}$ nedenle, modelin \%90 güvenilirlik düzeyinde istatistiksel olarak anlamlı olmadığı söylenebilir. Model yorumlamalarda kullanılamaz.

Tablo 12. 0,75 Kantil Değerine Sahip Regresyon Modeli $(\alpha=0,10)$

\begin{tabular}{ccccc}
\hline Değişkenler & Katsayı & Std. Hata & t-İstatistiği & p-değeri \\
\hline DBORC1 & $-0,060383$ & 0,143667 & $-0,420295$ & 0,6770 \\
\hline RDOVIZ1 & $-2,984183$ & 24,48747 & $-0,121866$ & 0,9037 \\
\hline RFAIZ1 & $-2,593457$ & 3,080615 & $-0,841863$ & 0,4059 \\
\hline TUFE1 & $-1,426489$ & 2,668048 & $-0,534656$ & 0,5965 \\
\hline C & 1,482952 & 0,690609 & 2,147312 \\
\hline \multicolumn{7}{c}{ Modele Ait İstatistikler } \\
\hline Pseudo R & \multicolumn{3}{c}{ Quasi-LR İstatistiği } \\
\hline Standart Hata & 0,1151 & p-değeri & 4,7178 \\
\hline
\end{tabular}

Not: ** ile işaretlenen değerleri \%10 anlamlılık düzeyinde istatistiksel olarak anlamlıdır.

Tablo 13'te 0,75 kantil değeri ve $\alpha=0,05$ değeri kullanılarak kurulan kantil regresyon modeli verilmiştir. Model sonuçlarına göre, BUYUME1 değişkeninin bağımlı değişken olduğu bu modelde yalnızca $\mathrm{C}$ sabit katsayısı $\% 95$ güvenilirlik düzeyinde istatistiksel olarak anlamlıdır.
C sabit katsayısındaki 1 birimlik değişim, BUYUME1 bağımlı değişkenini 1,482952 birim etkilemektedir. $\mathrm{Bu}$ modelin $\mathrm{R}^{2}$ değeri ise katsayısı \%11,51 olarak bulunmuştur. Fakat modelin p-değeri 0,05 anlamlılık düzeyinden büyük olduğu için $\mathrm{h}_{11 \text { a }}$ yokluk hipotezi "Gözlenen noktaların 
regresyon çizgisi ile korelasyonu ihmal edilebilir düzeydedir (model anlamlı değildir)." reddedilememektedir. $\mathrm{Bu}$ nedenle, modelin \%95 güvenilirlik düzeyinde istatistiksel olarak anlamlı olmadığı söylenebilir. Model yorumlamalarda kullanılamaz.

Tablo 13. 0,75 Kantil Değerine Sahip Regresyon Modeli $(\alpha=0,05)$

\begin{tabular}{ccccc}
\hline Değişkenler & Katsayı & Std. Hata & t-İstatistiği & p-değeri \\
\hline DBORC1 & $-0,060383$ & 0,153976 & $-0,392157$ & 0,6975 \\
\hline RDOVIZ1 & $-2,984183$ & 25,33788 & $-0,117776$ & 0,9070 \\
\hline RFAIZ1 & $-2,593457$ & 3,220645 & $-0,805260$ & 0,4264 \\
\hline TUFE1 & $-1,426489$ & 2,983224 & $-0,478170$ & 0,6357 \\
\hline C & 1,482952 & 2,034998 & $0,0499 *$ \\
\hline \multicolumn{5}{c}{ Modele Ait İstatistikler } \\
\hline Pseudo R & \multicolumn{3}{c}{ Quasi-LR İstatistiği } \\
\hline Standart Hata & 0,1151 & p-değeri & 4,4878 \\
\hline
\end{tabular}

Not: * ile işaretlenen değerleri \%5 anlamlılık düzeyinde istatistiksel olarak anlamlıdır.

Tablo 14’te 0,85 kantil değeri kullanılarak uygulanan kantil regresyon sonuçları verilmiştir. Her değişken için gözlem değerinin 38 olması nedeniyle yorumlanabilir sayısal sonuçlar veren en büyük kantil değeri 0,85 'tir. Bu nedenle sonuncu kantil değeri olarak 0,85 tercih edilmiştir. Tablodaki sonuçlara göre, BUYUME1 bağımlı değişken olduğu zaman RFAIZ1 değişkeni ve C sabit katsayısı \%90 güvenilirlik düzeyinde istatistiksel olarak anlamlılardır. RFAIZ1 değişkeni -4,977617'lik bir katsayıya sahip olduğundan bu değişkendeki her 1 birimlik artış
BUYUME1 bağımlı değişkenini $-4,977617$ birim negatif etkilemektedir. C katsayısı ise 2,383673'lük bir katsayı ile pozitif etki göstermektedir. Modelin $\mathrm{R}^{2}$ değeri ise $\% 10,41$ 'tür. Fakat modelin p-değeri 0,10 anlamlılık düzeyinden büyük olduğu için $\mathrm{h}_{12 \mathrm{a}}$ yokluk hipotezi "Gözlenen noktaların regresyon çizgisi ile korelasyonu ihmal edilebilir düzeydedir (model anlamlı değildir)." reddedilememektedir. $\mathrm{Bu}$ nedenle, modelin \%90 güvenilirlik düzeyinde istatistiksel olarak anlamlı olmadığı söylenebilir. Model yorumlamalarda kullanılamaz.

Tablo 14. 0,85 Kantil Değerine Sahip Regresyon Modeli $(\alpha=0,10)$

\begin{tabular}{ccccc}
\hline Değişkenler & Katsayı & Std. Hata & t-İstatistiği & p-değeri \\
\hline DBORC1 & $-0,191138$ & 0,213924 & $-0,893487$ & 0,3781 \\
\hline RDOVIZ1 & $-2,671610$ & 23,22662 & $-0,115024$ & 0,9091 \\
\hline RFAIZ1 & $-4,977617$ & 2,522800 & $-1,973053$ & $0,0569^{* *}$ \\
\hline TUFE1 & 1,570751 & 5,710969 & 0,275041 & 0,7850 \\
\hline C & 2,383673 & 0,873094 & 2,730146 & $0,0101^{* *}$ \\
\hline \multicolumn{5}{c}{ Modele Ait İstatistikler } \\
\hline Pseudo R & \multicolumn{3}{c}{ Quasi-LR İstatistiği } & 3,7758 \\
\hline Standart Hata & 0,1041 & p-değeri & 0,4371 \\
\hline
\end{tabular}

Not: ** ile işaretlenen değerleri \%10 anlamlılık düzeyinde istatistiksel olarak anlamlıdır.

Son olarak, Tablo 15 'te 0,85 kantil değeri kullanılarak $\alpha=0,05$ değeri için uygulanan kantil regresyon sonuçları verilmiştir. Bu sonuçlara göre RFAIZ1 değişkeni ve $\mathrm{C}$ sabit katsayısı istatistiksel olarak anlamlı bulunmuştur. RFAIZ1 değişkenindeki her 1 birimlik artış, BUYUME1 bağımlı değişkenini 4,977617 birim azaltmaktadır. C sabit katsayısı için ise her 1 birimlik artış bağımlı değişken üzerinde 2,383673 birimlik bir artış yapmaktadır. Modelin $\mathrm{R}^{2}$ değeri ise \%10,41'tür. Fakat modelin p-değeri 0,05 anlamlılık düzeyinden büyük olduğu için $h_{13 a}$ yokluk hipotezi "Gözlenen noktaların regresyon çizgisi ile korelasyonu ihmal edilebilir düzeydedir (model anlamlı değildir)." reddedilememektedir. $\mathrm{Bu}$ nedenle, modelin \%95 güvenilirlik düzeyinde istatistiksel olarak anlamlı olmadığı söylenebilir. Model yorumlamalarda kullanılamaz.

Tablo 15. 0,85 Kantil Değerine Sahip Regresyon Modeli $(\alpha=0,05)$

\begin{tabular}{ccccc}
\hline Değişkenler & Katsayı & Std. Hata & t-İstatistiği & p-değeri \\
\hline DBORC1 & $-0,191138$ & 0,172158 & $-1,110249$ & 0,2749 \\
\hline RDOVIZ1 & $-2,671610$ & 23,84938 & $-0,112020$ & 0,9115 \\
\hline RFAIZ1 & $-4,977617$ & 2,301568 & $-2,162707$ & $0,0379 *$ \\
\hline TUFE1 & 1,570751 & 4,201344 & 0,373869 & 0,7109 \\
\hline C & 2,383673 & 3,126804 & $0,0037 *$ \\
\hline \multicolumn{5}{c}{ Modele Ait İstatistikler } \\
\hline Pseudo R & \multicolumn{3}{c}{ Quasi-LR İstatistĭ̆ } & 3,7274 \\
\hline Standart Hata & 0,1041 & p-değeri & 0,4441 \\
\hline
\end{tabular}

Not: * ile işaretlenen değerleri $\% 5$ anlamlılık düzeyinde istatistiksel olarak anlamlıdır. 
Yukarıda 5 farklı kantil değeri için elde edilen regresyon modellerine ait denklemler, Tablo 16'da özetlenmiştir. Bu denklemler tartışma ve sonuç bölümünde yapılacak yorumlamalar için kullanılacaktır.

Tablo 16. Kantil Regresyon Model Denklemleri

\begin{tabular}{cc}
\hline & $\boldsymbol{\alpha}=\mathbf{0 , 1 0}$ \\
\hline \multirow{2}{*}{ Kantil Değeri } & Model Denklemleri \\
\hline 0,15 & $-0,174098 *$ RDOVIZ1 - 6,174832*TUFE1 - \\
& 3,035580 \\
\hline 0,25 & $-6,182354 *$ TUFE1 $-1,400511$ \\
\hline 0,50 & Model anlamsız bulunmuştur. \\
\hline 0,75 & Model anlamsız bulunmuştur. \\
\hline 0,85 & Model anlamsız bulunmuştur. \\
\hline & $\boldsymbol{\alpha}=\mathbf{0 , 0 5}$ \\
\hline \multirow{2}{*}{ Kantil Değeri } & Model Denklemleri \\
\hline 0,15 & Model anlamsız bulunmuştur. \\
\hline 0,25 & Anlamlı bağımsiz değişken bulunamamıştır. \\
\hline 0,50 & Model anlamsı bulunmuştur. \\
\hline 0,75 & Model anlamsız bulunmuştur. \\
\hline 0,85 & Model anlamsız bulunmuştur. \\
\hline
\end{tabular}

\section{Tartışma ve Sonuç}

Türkiye'nin ekononomik büyüme oranına etki eden faktör veya faktörleri incelemek amacıyla yapılan bu çalışmada 5 farklı değişken kullanılmıştır. Bu değişkenlerden birisi olan "ekonomik büyüme oranı" bağımlı değişken olarak kullanılmıştır. "Dış borç stoku (milyon \$)", "TÜFE bazlı reel efektif döviz kuru", "reel faiz oranı" ve "tüketici fiyatları endeksi (enflasyon)" birer bağımsız değişken olarak belirlenmiştir. Daha sonra, değişkenler arasındaki korelasyon ilișkilerine dair değerler verilmiş ve incelenmiştir. Çalışmada kullanılan tüm değişkenler zamana bağlı olduğundan dolayı birer zaman serisidir. $\mathrm{Bu}$ nedenle, değişkenlerin durağanlıkları (birim kök) ADF testi ile test edilmiştir. Test sonucunda tüm değişkenlerin 1.dereceden farkları alınarak durağanlaşma sağlanmıştır. Böylelikle EKK yöntemi ile regresyon modeli kurmak için uygun hale gelen değişkenlerle bir regresyon modeli kurulmuştur. EKK yöntemi ile kurulan model sonuçlarına göre, "ekonomik büyüme oranı" bağımlı değişkeni üzerinde "TÜFE bazlı reel efektif döviz kuru" değişkeninin 0,148391'lik, "tüketici fiyatlar1 endeksi (enflasyon)" değişkeninin ise -4,264171'lik bir negatif etkisi vardır. Kurulan bu model üzerinde regresyon varsayımları incelenmiştir. Model, normallik varsayımını sağlamasına rağmen aykırı değerler içerdiğinden dolayı EKK yönteminin kullanılması uygun değildir. Bu nedenle EKK yöntemi ile regresyona alternatif bir yöntem olan kantil regresyonun kullanılmasına karar verilmiştir.
EKK yöntemine karşı alternatif olarak kullanılan kantil regresyon için uygun kantil değerleri $0,15,0,25,0,50,0,75$ ve 0,85 olarak belirlenmiştir. $\mathrm{Bu}$ kantil değerleri kullanılarak toplamda 10 ayrı regresyon modeli oluşturulmuştur. Modeller $\alpha=0,10$ ve $\alpha=0,05$ anlamlilik düzeylerinde test edilmiştir. $\alpha=0,05$ düzeyinde modellerin anlamsız bulunması sebebiyle $\alpha=0,01$ anlamlılık düzeyinin kullanılmasına ihtiyaç duyulmamıştır. Sonuç olarak, bu modellerden yalnızca üç model istatistiksel olarak anlamlı bulunmuştur. $\alpha=0,10$ düzeyinde 0,15 kantil değeri ile oluşturulan ilk modelde "ekonomik büyüme oranı"nı "TÜFE bazlı reel efektif döviz kuru"ndaki her 1 birimlik artış 0,174098 birim negatif; "tüketici fiyatları endeksi (enflasyon)"ndeki her 1 birimlik artış da 6,174832 birim negatif yönlü etkilemektedir. İstatistiksel olarak anlamlı bulunan ikinci model ise $\alpha=0,10$ düzeyinde 0,25 kantil değeri kullanılarak oluşturulan modeldir. $\mathrm{Bu}$ modelde, "TÜFE bazlı reel efektif döviz kuru"ndaki her 1 birimlik artış "ekonomik büyüme oranı"nı 6,182354 birim negatif yönlü etkilemektedir. Ayrıca bu modelde - 1,400511'lik sabit katsayı etkisi de mevcuttur. 0,25 kantil değeri kullanılarak $\alpha=0,05$ düzeyinde oluşturulan ve istatistiksel olarak anlamlı bulunan sonuncu modelde ise anlamlı hiçbir bağımsız değişken olmadığından yorumlama yapılamamıştır.

Oluşturulan tüm modellerden elde edilen sonuçlara göre, "ekonomik büyüme oranı" üzerinde "TÜFE bazlı reel efektif döviz kuru" değişkeninin yalnızca bir modelde, "enflasyon" değişkeninin ise iki modelde negatif bir etkisi olduğu gözlemlenmiştir. Bulunan iki modelde "enflasyon" ortak değişken olarak bulunmuştur. 2010Q1-2019Q3 döneminde Türkiye'deki ekonomik büyüme oranlarındaki artış, enflasyon ve TÜFE bazlı reel efektif döviz kuru değerleri ile ters orantılı bulunmuştur.

Türkiye'nin 2018 yılına kadar son 10 y1lda en çok ihracat yaptığı ülkeler incelendiğinde Almanya bașta olmak üzere; İtalya, İspanya, Fransa ve Hollanda'nın ilk 10 ülke arasında yer aldığı görülmektedir (Koşar, 2018: 23). 2019 yılı ihracat verilerine bakıldığında da bu durumun değişmediği görülmektedir (Habertürk, 2019). Bu 5 ülkede kullanılan para birimi Euro olması ve bu ülkelerin TÜFE bazlı reel efektif döviz kuru endeksine dahil olan ülkelere (reel efektif döviz kuru hesabında 42 ülkeye ait değerler kullanılır) dahil olması nedeniyle, "TÜFE bazlı reel efektif döviz kuru"nun "ekonomik büyüme oranı"nı negatif etkilemesi beklendik bir sonuçtur (TCMB, 2020). Fatih (2019), yapmış olduğu çalışmada reel döviz kurunun, ekonomik büyüme göstergesi olan sanayi üretimi üzerinde negatif etkisinin olduğunu tespit etmiştir. $\mathrm{Bu}$ sonuç, kantil regresyon sonucunda bulunan "TÜFE bazlı reel efektif döviz kuru", ekonomik büyümeyi negatif etkiler olgusunu destekler niteliktedir. Ayrıca, "ekonomik büyüme oranı" üzerinde her iki model için enflasyonun da negatif bir etkisi bulunmuştur. Yapraklı (2007), yapmış olduğu çalışmada buna benzer bir sonuç bulmuştur. Yapılan çalışmada, 1987Q1-2007Q1 döneminde Türkiye'ye ait ekonomik büyüme oranları üzerinde enflasyonun negatif etkisi olduğu sonucuna varılmıştır. Benzer şekilde, Toker ve Gürel (2019), yapmış oldukları çalışma sonucunda artan enflasyonun ekonomik büyümeyi azalttığına dair sonuca ulaşmıştır. Sonuç olarak, TCMB'ye ve politika yapıcılara, istikrarlı bir ekonomik büyüme oranını yakalamak için enflasyon oranının düşük seviyede (tek hanede) olmasını 
sağlayacak reformları uygulaması ve Türk Lirası'nın yabancı para birimleri karşısında değer kaybının önlenmesi önerilmektedir. $\mathrm{Bu}$ çalışmada elde edilen sonuçlar, ekonomik büyüme oranı ile yapılacak olan çalışmalar için önemli bir değerlendirme olarak görülmekte ve başka çalışmalarda kurulacak olan modellere, anlamlı bulunan bu iki değişkenin eklenmesi önerilmektedir.

\section{Kaynakça}

Acarlar, I. (2011). Comparison of Diagnostic Methods for Detecting an Influential Observation in Regression. Anadolu University Journal of Science and Technology, 1(2), 105-116.

Acemoglu, D. (2012). Introduction to Economic Growth. Journal of Economic Theory, 147, 545-550.

Adeniran, J.O., Yusuf, S.A., \& Olatoke, A.A. (2014). The Impact of Exchange Rate Fluctuation on the Nigerian Economic Growth: An Empirical Investigation. International Journal of Academic Research in Business and Social Sciences, 4(8), 224233.

Andres, J., \& Hernando, I. (1999). The Costs and Effects of Price Stability. Editor: Feldstein, M. eChicago: The University of Chicago Press, 315-341.

Aslam, A.L.M. (2016). Impact of Exchange Rate on Economic Growth in Sri Lanka. World Scientific News 54, 252-266.

Ayhan, F. (2019). Türkiye İçin Kısa Vadeli Sermaye Akımlarıve Reel Döviz Kurunun Ekonomik Büyüme Üzerine Etkilerine İlişkin Uygulamalı Bir Araştırma. Journal of Yasar University, 14(54), 106-118.

Ayyoub, M., Chaudhry, I.S., \& Farooq, F. (2011). Does Inflation Affect Economic Growth? The Case of Pakistan. Pakistan Journal of Social Sciences (PJSS), 31(1), 51-64.

Belsley, D.A., Kuh, E., \& Welsch, R.E. (1980). Regression Diagnostics, Identifying Influential Data and Sources of Collinearity. New York, Chichester: John Wiley \& Sons.

Conyon, M.J., \& He, L. (2017). Firm Performance and Boardroom Gender Diversity, A Quantile Regression Approach. Journal of Business Research, 79, 198-211.

Çelikkol, H., \& Köse, F. (2015). Türkiye'de Elektrik Finansal Piyasaları Arasındaki Nedensellik İlişkisinin Analizi. International Journal of Social Sciences and Education Research, 1(3), 814-823.

Darity, W.A. (2008). Ordinary Least Squares Regression. International Encyclopedia of the Social Sciences, 2(6), 57-61.

Dickey, D.A., \& Fuller, W.A. (1979). Distribution of the Estimators for Autoregressive Time Series with a
Unit Root. Journal of The American Statistical Association, 74(366), 427-431.

Dickey, D.A., \& Fuller, W.A. (1981). Likelihood Ratio Statistics for Autoregressive Time Series with a Unit Root. Econometrica, Journal of the Econometric Society, 49(4), 1057-1072.

Erbaykal, E., \& Okuyan, H.A. (2008). Does Inflation Depress Economic Growth? Evidence from Turkey. International Journal of Finance end Economics, 13(17), 40-48.

Foussier, P. (2010). Improving CER Building, Basing a CER on the Median. Journal of Cost Analysis and Parametrics, 3(2), 1-12.

Göçer, İ., \& Gerede, C. (2016). Cari Açık-Ekonomik Büyüme-Enflasyon ve İşsizlik Açmazında Türkiye, Yeni Nesil Bir Ekonometrik Analiz. Anadolu Üniversitesi Sosyal Bilimler Dergisi, 16(5), 35-46.

Gujarati, D.N. (2001). Temel Ekonometri. Gülay Günlük Şenesen \& Ümit Şenesen (Çev.). İstanbul: Literatür Yayıncilik.

Habertürk, 2019 Dış Ticaret Rakamları Açıklandı: https://www.haberturk.com/2019-ihracat-rakamlariaciklandi-2555282-ekonomi (Erişim: 17.02.2020).

Hadi, A.S., \& Simonoff, J.S. (1993). Procedures for the Identification of Multiple Outliers in Linear Models. Journal of the American Statistical Association, 88(424), 1264-1272.

Henisz, W.J. (2000). The Institutional Environment For Economic Growth. Economics and Politics, 12(1), 1-31.

Horn, R.A., \& Johnson, C.R. (1985). Topics in Matrix Analysis. Cambridge: Cambridge University Press.

Hussin, A.G., \& Abuzaid, A. (2012). Detection Of Outliers In Functional Relationship Model For Circular Variables Via Complex Form. Pakistan Journal of Statistics, 28(2), 205-216.

Karabulut, Ş. (2019). Türkiye'de Ekonomik Büyüme ve Enflasyon İlişkisi. Optimum Ekonomi ve Yönetim Bilimleri Dergisi, 6(2), 171-184.

Kasidi, F., \& Mwakanemela, K. (2013). Impact of Inflation on Economic Growth: A Case Study of Tanzania. Asian Journal of Empirical Research, 3(4), 363-380.

Koenker, R. (1984). A Note on L-estimators for Linear Models. Statistics \& Probability Letters 2, 323-325.

Koenker, R., \& Bassett, G. (1978). Regression Quantiles. Econometrica, 46(1), 33-50.

Koopmans, T.C. (1965). On the Concept of Optimal Economic Growth. In the Econometric Approach to Development Planning. North Holland, Amsterdam.

Koşar, A. (2018). Türkiye'nin Son 10 Yılda En Çok İhracat ve İthalat Yaptığı Ülkelerin Hiyerarşik Kümeleme Analizi ile Gruplandırılması ve Değerlendirilmesi. Bucak Işletme Fakültesi Dergisi, 1(1), 17-28. 
Kutlu, S., \& Yurttagüler, İ.M. (2016). Türkiye'de Diş Borç ve Ekonomik Büyüme İlişkisi, 1998-2014 Dönemi İçin Bir Nedensellik Analizi. Marmara Üniversitesi İktisadi ve İdari Bilimler Dergisi, 38(1), 229-248.

Kuznets, S. (1967). Modern Economic Growth. Yale University Press.

Levine, R., \& Zervos, S. (1998). Stock Markets, Banks, and Economic Growth. The American Economic Review, 88(3), 537-558.

Maiti, M. (2019). OLS Versus Quantile Regression in Extreme Distributions. Contaduria y Administración, 64(2), 1-11.

Mallik, G., \& Chowdhury, A. (2001). Inflation and Economic Growth: Evidence from South Asian Countries. Asian Pacific Development Journal, 8(1), 123-135.

Marquis, H.M., \& Reffett, K.L. (1995). The Inflation Tax in a Convex Model of Equilibrium Growth. Economica, 62(245), 109-121.

Mukoka, S. (2018). An Econometric Assessment of the Impact of Inflation on Economic Growth: A Case Study of Zimbabwe Economy. Economics, 7(1), 1722.

Ozpence, A.I. (2016). Analysis of the Relationship Between Inflation and Economic Growth in Turkey. Journal of Economics Finance and Accounting, 3(3), 180191.Perron, P. (1989). The Great Crash, the Oil Price Shock, and the Unit Root Hypothesis. Econometrica, 57(6), 1361-1401.

Sevüktekin, M., \& Çınar, M. (2014). Ekonometrik Zaman Serileri Analizi. Bursa: Dora Yayıncılık.

Solow, R. (1956). A Contribution to the Theory of Economic Growth. Quarterly Journal of Economics, 70 .

Şentürk, M., \& Akbaş, Y.E. (2014). İşsizlik-Enflasyon ve Ekonomik Büyüme Arasindaki Karşilikli İlişkinin Değerlendirilmesi, Türkiye Örneği. Journal of Yasar University, 9(34), 5820-5832.

Toker, K., \& Gürel, S.P. (2019). Enflasyon- Ekonomik Büyüme İlişkisi, Türkiye Ekonomisinde MundellTobın Etkisinin Analizi. Pamukkale Üniversitesi Sosyal Bilimler Enstitüsü Dergisi, 36, 335-348.
Topcu, E. (2017). Enflasyon-Ekonomik Büyüme İlişkisi, Türkiye Örneği. Nevşsehir Hacı Bektaş Veli Üniversitesi SBE Dergisi, 7(2), 180-191.

TCMB, Elektronik Veri Dağıtım Sistemi (EVDS): https://evds2.tcmb.gov.tr/index.php?/evds/serieMark et (Erişim: 05.02.2020).

TCMB, Reel Efektif Döviz Kuru: https://www.tcmb.gov.tr/wps/wcm/connect/0271354 5-8428-49ab-a9d9-

0f770895d513/REERMetaveri.pdf?MOD=AJPERE S\&CACHEID=ROOTWORKSPACE-027135458428-49ab-a9d9-0f770895d513-mBdDyxu (Erişim: 03.10.2020).

Türkiye İstatistik Kurumu (TÜİK), Temel İstatistikler: http://www.tuik.gov.tr/UstMenu.do?metod=temelist (Erişim: 05.02.2020).

What-when-how, In Depth Tutorials and Information, Ordinary Least Squares Regression (Social Science): http://what-when-how.com/social-sciences/ordinaryleast-squares-regression-social-science/ (Erişim: 08.02.2020).

$\mathrm{Xu}$, B., \& Lin, B. (2018). Investigating the Differences in CO2 Emissions in the Transport Sector Across Chinese Provinces: Evidence From a Quantile Regression Model. Journal of Cleaner Production, 175(2018), 109-122.

Yamak, R., \& Tanrı̈ver, B. (2009). Faiz Oranı, Getiri Fark1 ve Ekonomik Büyüme, Türkiye Örneği (1990-2006). Dokuz Eylül Üniversitesi İktisadi ve İdari Bilimler Fakültesi Dergisi, 24(1), 43-58.

Yardımcı, P. (2006). İçsel Büyüme Modelleri ve Türkiye Ekonomisinde İçsel Büyümenin Dinamikleri. Karamanoğlu Mehmetbey Üniversitesi Sosyal Ve Ekonomik Araştırmalar Dergisi, 2006(1), 96-114.

Yavuz, A.A., \& Aşık, E.G. (2017). Quantile Regression. Uluslararası Mühendislik Araştırma ve Geliştirme Dergisi, 9(2), 138-146.

Yapraklı, S. (2010). Enflasyon ve Ekonomik Büyüme Arasındaki İlişki: Türkiye İçin Eş-Bütünleşme ve Nedensellik Analizi. Atatürk Üniversitesi Sosyal Bilimler Enstitüsü Dergisi, 10(2), 287-301. 